\title{
Review
}

\section{Caspase inhibitors}

\author{
PG Ekert ${ }^{*, 1}, J_{\text {Silke }}{ }^{1}$ and DL Vaux ${ }^{1}$ \\ 1 The Walter and Eliza Hall Institute of Medical Research, c/o Post Office Royal \\ Melbourne Hospital, Victoria 3050, Australia \\ * Corresponding author: PG Ekert, The Walter and Eliza Hall Institute of Medical \\ Research, c/o Post Office Royal Melbourne Hospital, Victoria 3050, Australia. \\ Tel: +61 39345 2548; Fax: +61 39347 0852; E-mail: ekert@wehi.edu.au
}

Received 26.4.99; revised 23.8.99; accepted 23.8.99

Edited by G Melino

\begin{abstract}
Caspases are the key effector molecules of the physiological death process known as apoptosis, although some are involved in activation of cytokines, rather than cell death. They exist in most of our cells as inactive precursors (zymogens) that kill the cell once activated. Caspases can be controlled in two ways. The processing and activation of a caspase can be regulated by molecules such as FADD, APAF-1, Bcl-2 family members, FLIP and IAPs. Active caspases can be controlled by a variety of inhibitors that directly interact with the protease. This review describes the later direct caspase inhibitors that have been identified, products of both viral and cellular genes, and artificial caspase inhibitors that have been developed both as research tools and as pharmaceutical agents to inhibit cell death in vivo.
\end{abstract}

Keywords: caspase; viral inhibitors; peptide inhibitors; IAPs

Abbreviations: crmA, cytokine response modifier A; IAP, inhibitor of apoptosis proteins; ICE, interleukin $1 \beta$ converting enzyme

\section{Viral and cellular caspase inhibitors}

Viruses must co-opt a cell's synthetic machinery in order to reproduce. Therefore a most effective way of preventing viral replication is for an infected cell to kill itself. However, just as apoptosis is used to defend against viruses, viruses carry cell death inhibitors to block this response of their host cells. Several viral cell death inhibitors act by binding to activated caspases.

The first caspase inhibitor to be identified was the Cowpox virus product Cytokine Response Modifier A (CrmA), which was found to inhibit Caspase 1 (Interleukin $1 \beta$ converting enzyme, or ICE). ${ }^{1}$ As crmA was discovered before the role of caspases in apoptosis had been established, it was hypothesized that viruses used CrmA to bind to active Caspase 1 to reduce the defensive inflammatory response triggered by $\mathrm{IL}-1 \beta .^{2}$
While this is indeed true, with the identification of caspases as the key mediators of apoptosis it also became clear that CrmA could be used to prevent defensive suicide of infected cells, thereby allowing more time for viral replication. ${ }^{3}$ These observations also highlighted the close association between inflammation and defensive apoptosis.

\section{CrmA}

CrmA can bind to and inhibit Caspase 1 with an inhibitory constant $\left(\mathrm{K}_{\mathrm{i}}\right)$ of $\sim 10$ picomolar and Caspase 8 with a $\mathrm{K}_{\mathrm{i}}$ of less than $300 \mathrm{pM}$ (Table 1). In this way crmA can prevent production of mature IL-1 $\beta$ and IL-18 by Caspase 1 , and apoptosis triggered by TNF receptor family members, which is mediated by Caspase $8 .{ }^{4-6}$ The inhibitory constants indicate crmA is unlikely to inhibit caspases 3, 6, 7 in vivo ${ }^{7,8}$ whilst there is some discrepancy in results regarding Caspase 10.8, Although it inhibits caspase 9 with a $\mathrm{K}_{\mathrm{i}}$ of $2 \mathrm{nM}$ in vitro, the fact that lymphocytes from Caspase 9 knock out animals were resistant to dexamethasone, but lymphocytes from transgenic mice expressing crmA were not, ${ }^{10,11}$ suggests crmA cannot inhibit Caspase 9 in vivo.

These data raise an important point, which is, how much does the in vitro determined inhibition constant reflect the physiological role of the caspase inhibitor? The above data might suggest that to be effective in vivo, a caspase inhibitor must have a $K_{i}$ of $\leqslant 1 \mathrm{nM}$. It should be remembered that the $\mathrm{K}_{\mathrm{i}}$ determined in vitro may not reflect the activity inside a cell. In vitro translated protein may not be properly folded, may lack important post-translational modifications and the physiological relevance of the in vitro determined $\mathrm{K}_{i}$ would depend on the relative abundance of the caspase and its inhibitor within the cell.

Structurally, crmA belongs to the serine protease inhibitor (serpin) group, but unlike other serpins, it inhibits caspases, which are cysteine proteases. ${ }^{1,12}$ However, like conventional serpins crmA acts as a pseudosubstrate that binds to the active proteases. The pseudosubstrate region of crmA has the residues LVAD (designated P4 - P1). Cleavage of caspase substrates (including crmA) occurs after the aspartate residue (P1).

Many serpins undergo a dramatic structural change from a 'stressed' to 'relaxed' conformation when they interact with serine proteases. While some serpins remain in an inhibitory complex with the protease after they are cleaved, it is thought that some CrmA molecules remain intact after binding to Caspase 1 to form an inhibitory complex, while cleaved CrmA polypeptides are released. ${ }^{12,13}$

CrmA has been genetically engineered in order to make variants that are able to inhibit other caspases, ${ }^{14,15}$ To do this the tetrapeptide pseudosubstrate region of crmA (LVAD) was replaced with tetrapeptides that are optimal 
Table 1 Inhibition of mammalian Caspases by viral and mammalian Caspase inhibitors

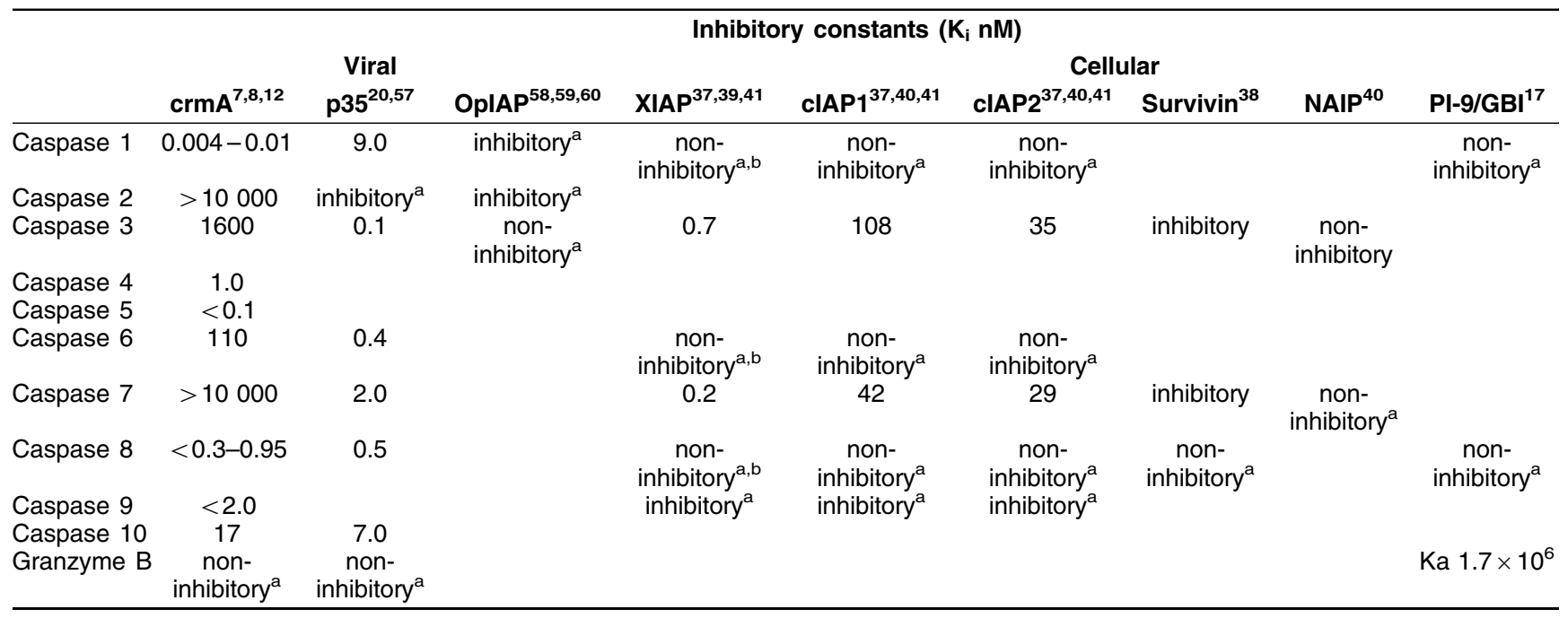

${ }^{a}$ Assignment as inhibitory or non-inhibitory is based on functional assays such as fluorogenic substrate cleavage, processing of Caspase or cell

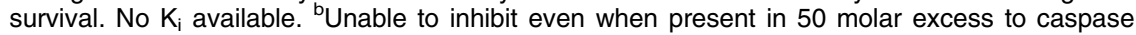

substrates for the different families of caspases, or with the four residues from the cleavage site of the baculovirus protein p35 (DQMD). These crmA variants showed altered ability to block caspases and protect against cell death. For example, unlike wild-type crmA, crmA.DQMD was able to inhibit ced-3 mediated deaths in $C$. elegans, ${ }^{14}$ reduce growth inhibition of yeast expressing Caspase $3,^{16}$ and protect lymphoid cells from death due to radiation or dexamethasone. ${ }^{15}$

\section{PI-9}

The closest mammalian homolog of crmA is the serine protease inhibitor leukocyte elastase inhibitor, but this serpin does not have an acidic residue in its active (P1) site, and cannot inhibit caspases. The cytotoxic lymphocyte serpin proteinase inhibitor 9 ( $\mathrm{PI}-9)$ (also known as granzyme $\mathrm{B}$ inhibitor (GBI)) is also a close relative of crmA, but is unique among vertebrate serpins in having an acidic residue in its pseudosubstrate region. Although in $\mathrm{PI}-9$ this is a glutamate residue rather than the aspartate found in crmA, it raised the possibility that $\mathrm{PI}-9$ might be able to inhibit caspases. In experiments in vitro it turned out that PI-9 does not inhibit caspases, but can inhibit granzyme B. Consistent with this, it can protect against granzyme B-mediated apoptosis, but not killing stimulated by the CD95 pathway, which uses Caspase 8. $^{17,18}$

\section{p35}

p35 is a baculoviral protein that can block the defensive apoptotic response of insect cells to viral infection. ${ }^{19}$ As well as being able to inhibit several insect caspases, p35 can inhibit $C$. elegans CED-3 (Table 3 ) and mammalian Caspases $1,3,6,7,8$, and 10 with $K_{i}$ values of less than $10 \mathrm{nM}$ (Table 1), but does not inhibit non-caspase cysteine proteases or serine proteases. After it is cleaved at its $\mathrm{P} 1$ residue (Asp87) by the caspase, p35 forms a complex that can be dissociated by SDS. ${ }^{20}$ As the cleaved subunits of p35 remain in an inhibitory complex with the caspases, p35 works in a fundamentally different manner to crmA.

p35 is able to inhibit caspases in vivo. In Drosophila, transgenic expression of p35 was able to prevent apoptotic death of cells in the developing embryo and eye. ${ }^{21,22}$ In $C$. elegans, transgenically expressed p35 could inhibit developmental cell death and block ced-3 induced cleavage of $\mathrm{PARP}^{14}$ and in mice, transgenic p35 rendered thymocytes resistant to several apoptosis-inducing agents. ${ }^{23}$ In experiments analogous to those varying the pseudosubstrate site of crmA, replacement of the p35 caspase substrate sequence (DQMD) with the reactive site of crmA (LVAD) resulted in p35 inhibiting Caspase 1 and Caspase 8 well, but increased the $\mathrm{K}_{\mathrm{i}}$ for Caspase 320 -fold. Further, this mutant became a substrate for Granzyme B. ${ }^{20}$

\section{IAPs}

Inhibitor of apoptosis (IAP) proteins were identified by Lois Miller and colleagues as baculoviral products that could suppress apoptosis of cells infected with a p35-deleted baculoviral strain. ${ }^{24}$ Subsequently genetic and sequence based experiments identified a group of cellular IAP homologs in yeasts, $C$. elegans, Drosophila and vertebrates, as well as in a number of other viruses (reviewed in Uren et $\mathrm{al}^{25}$ and LaCasse et $\mathrm{al}^{26}$ ). All members of this family bear from one to three baculoviral IAP repeats (BIRs), which mediate all interactions between IAPs and other proteins described to date.

Although there is evidence implicating many IAPS in the regulation of apoptosis, for several, such as the IAP in Autographa californica NPV, one of the two IAPs in Orgyia pseudosugata NPV, no such role has been demonstrated, 
and the nature of their true function has not been determined. One group of IAPs, including those from the yeasts $S$. pombe and $S$. cerevisiae, the mammalian protein Survivin, and the IAPs from $C$. elegans (bir1 and bir2), have BIRs that form a structural sub-group. ${ }^{25}$ Emerging evidence suggests these IAPs may function in cytokinesis rather than in regulation of apoptosis. ${ }^{27-29}$

Precisely how the anti-apoptotic IAPs function is not known with certainty. Genetic and biochemical experiments in insect systems suggest some IAPs can act via interactions with apoptosis activating proteins such as grim, reaper and hid. ${ }^{30-35}$ Recent data suggest grim, reaper and hid are upstream of the IAPs, and that the inhibition of the IAP-caspase interaction is the mechanism by which grim, reaper and hid induce apoptosis. ${ }^{36}$ However, there is also biochemical evidence that insect and vertebrate IAPs can inhibit apoptosis by directly binding to the activated caspases themselves. Drosophila DIAP1 can inhibit mammalian Caspase 3 (Table 3). In this review of caspase inhibitors we will only discuss the latter activity.

The mammalian IAPS XIAP (MIHA, hILP), MIHB (cIAP1), MIHC (c-IAP2), NAIP and Survivin have all been reported to be able to bind to and inhibit caspases, but the inhibitory constants of XIAP and Survivin are considerably lower than the other IAPs (Table 1) which may imply more potent (or more physiological) function in vivo. XIAP and Survivin are reported to inhibit Caspases 3 and 7 with $\mathrm{K}_{\mathrm{i}}$ 's of 0.7 and $0.2 \mathrm{nM}$ respectively, ${ }^{37,38}$ which is similar to the $\mathrm{K}_{\mathrm{i}}$ of crmA for Caspase 8. Deletion analysis of XIAP suggests its middle BIR, BIR2, is necessary and sufficient to bind to and inhibit activate Caspases 3 and $7 .^{39}$

MIHB, MIHC and NAIP on the other hand have not been found to inhibit any caspases with a $\mathrm{K}_{\mathrm{i}}$ of less than $29 \mathrm{nM}^{40}$ The fact that this is three times higher than the $\mathrm{K}_{\mathrm{i}}$ of crmA for Caspase 9 (which appears to be insufficient for it to inhibit caspase 9 mediated apoptosis in vivo) suggests these IAPs mainly act in some other way. Consistent with this notion, MIHB and MIHC were required to be at $100-$ 1000-fold molar excess in order to inhibit Caspases 3 and 7 by more than $50 \%,{ }^{40}$ and these levels probably never occur in vivo.

Survivin is reported to inhibit caspases as potently as $\mathrm{XIAP},{ }^{38}$ which is able to block apoptosis triggered by ligation of CD95 (Fas/APO-1), dexamethasone or Bax expression. ${ }^{41}$ Curiously, like most transformed cell lines, Jurkat $T$ cells express abundant Survivin, ${ }^{42}$ but remain sensitive to killing by ligation of CD95, dexamethasone and Bax expression. As Survivin is expressed in cells that are rapidly dividing (i.e. embryonal tissues and tumor lines but not in adult tissues) and is able to associate with tubulin, Survivin's function may not be to regulate apoptosis but to mediate events during cell division. ${ }^{27}$

When apoptosis is inhibited by XIAP, MIHB or MIHC, the cells do not accumulate processed caspases complexed with the IAPs, but are found to have increased amounts of pro-caspases. ${ }^{37,40,43}$ The initial suggestion that this may be due to the IAPs binding Caspase 3 as it became activated, thereby preventing autocatalysis of the remaining proCaspase 3 seems not to be correct as activated Caspase
3 is not capable of activating pro-Caspase $3 .^{44}$ The finding that the IAPs can also bind pro-Caspase $9^{41}$ may provide the answer to this puzzle, as by doing so they would prevent processing of other, downstream caspases, including Caspase 3. To date the association of IAPs with pro-caspases has not been confirmed in intact cells.

\section{Synthetic caspase inhibitors}

As inappropriate apoptosis has been implicated in many diseases, including ischemic vascular diseases (heart attacks, stroke) and degenerative diseases (Alzheimer's disease, motor neurone disease) there has been a tremendous effort to develop caspase inhibitors for pharmacological use. Such synthetic caspase inhibitors are of course also useful for analysis of caspase activity in experimental models.

Caspases are one of about 20 families of cysteine proteases. Some of the cysteine protease inhibitors such as iodoacetamide react with the catalytic cysteine in caspases, and can therefore inhibit them, but these inhibitors are not specific for caspases.

A number of specific caspase inhibitors have been developed based upon the substrate cleavage sites of the caspases. These peptides act as pseudosubstrates for active caspases and are therefore competitive inhibitors. They range from those containing a single aspartate residue (e.g. Boc-aspartyl(OMe)-fluoromethylketone: BocAsp-FMK) to trimers (e.g. Benzyloxycarbonyl-val-ala-asp (OMe) fluoromethylketone: z-VAD-FMK) to tetramers (e.g. YVAD-FMK).

The chemical mechanism of action of the synthetic inhibitors is determined by the chemical groups to which the peptides are linked. Linking the appropriate peptide to fluoro- or chloro-methyl ketones (-CMK, -FMK) groups produces irreversible, competitive inhibitors. A thiomethyl ketone II forms with the active site cysteine resulting in inactivation of the enzyme. ${ }^{45}$ The halomethyl ketones are highly reactive and may not be entirely specific for caspases. Peptides linked to aldehyde groups (-CHO) (or nitriles or ketones) act as reversible inhibitors. These act as caspase substrates without chemically altering the protease. The rate limiting step for both classes of inhibitor seems to be the enzyme-inhibitor association (reviewed in Thornberry et $a l^{46}$ ). While potent in vitro, the activity of peptide caspase inhibitors in intact cells is limited by their membrane permeability. The -FMK adducts are much more permeable than the aldehyde based inhibitors, which enter cells poorly, and do not inhibit any caspases in intact cells at concentrations less than $1 \mu \mathrm{M}$. This is probably because the -FMK derivative are prepared as methyl esters of the P1 aspartic acid. In general the shorter peptides are more permeable than the tetramers.

The peptide caspase inhibitors are able to block caspase activity in vitro with $\mathrm{K}_{\mathrm{i}}$ 's down to the high picomolar-low nanomolar range (Table 2). The halomethyl ketone-linked peptide YVAD has similar kinetics to the aldehyde linked peptide. $^{45}$ Ac-WEHD-CHO, Ac-DEVD-CHO, Ac-YVAD$\mathrm{CHO}$, t-butoxycarbonyl-IETD-CHO, and t-butoxycarbonylAEVD-CHO display a wide range of selectivity and 
potencies against caspases, with dissociation constants ranging from $75 \mathrm{pM}$ to $>10 \mu \mathrm{M}^{8}$ The results obtained with peptide-based inhibitors are in accord with those predicted from the substrate specificity studies. ${ }^{47}$

Although these protease inhibitors are more specific than general cysteine protease inhibitors such as iodoacetamide, z-VAD-FMK, z-DEVD-FMK and AcYVAD-CMK are all capable of efficiently inhibiting other proteases, such as cathepsin B, both in vitro and in tissue culture at concentrations that are generally used to demonstrate the involvement of caspases. ${ }^{48}$ YVAD$\mathrm{CHO}$ is probably the most specific of the commonly used caspase inhibitors as it only potently inhibits Caspase..$^{8,49}$ The other caspase inhibitors do not target individual caspases. For example, while it is not usually regarded as a broad range caspase inhibitor and most potently inhibits Caspase 3, DEVD-CHO also strongly inhibits Caspases 7 and 8.,49 $^{8-V A D-C H O}$ can strongly inhibit Caspases 1, 3, 5, 7, 8, and 9, but is not a good inhibitor of Caspase $2 .^{8}$

\section{In vivo use}

While the peptide based caspase inhibitors are first generation drugs that have been useful in cell extracts and in tissue culture, a number of experiments describe their use in vivo, and suggest that caspase inhibitors will one day be

Table 2 Inhibitory constants of synthetic caspase inhibitors for mammalian Caspases

\begin{tabular}{|c|c|c|c|}
\hline & \multicolumn{3}{|c|}{ Inhibitory constants ( $\left.K_{i} n M\right)$} \\
\hline & Z-VAD-FMK ${ }^{8}$ & $\begin{array}{l}\text { Ac-DEVD- } \\
\text { CHO }^{8,44,49}\end{array}$ & $\begin{array}{c}\text { Ac-YVAD- } \\
\text { CHO }^{8,49}\end{array}$ \\
\hline Caspase 1 & $2.5^{\mathrm{a}}$ & $15-18$ & 0.76 \\
\hline Caspase 2 & $2400^{a}$ & 1710 & $>10000$ \\
\hline Caspase 3 & $43^{a}$ & $0.23-2.2$ & $>10000$ \\
\hline Caspase 4 & $130^{a}$ & 132 & 362 \\
\hline Caspase 5 & $5.3^{\mathrm{a}}$ & 205 & 163 \\
\hline Caspase 6 & $98^{\mathrm{a}}$ & 31 & $>10000$ \\
\hline Caspase 7 & $39^{a}$ & 1.6 & $>10000$ \\
\hline Caspase 8 & $2.5^{\mathrm{a}}$ & 0.92 & 352 \\
\hline Caspase 9 & $3.9^{\mathrm{a}}$ & 60 & 970 \\
\hline Caspase 10 & & 12 & 408 \\
\hline
\end{tabular}

aalue shown is $t_{1 / 2}$ at $1 \mu \mathrm{M}$ in seconds

Table 3 Inhibition of other Caspases by Drosophila IAPs and p35. Inhibition is based on functional assays. drICE and DCP1 are Drosophila caspases. CED3 is a $C$. elegans caspase. sfCasp1 is an insect caspase from Spodoptera frugiperda

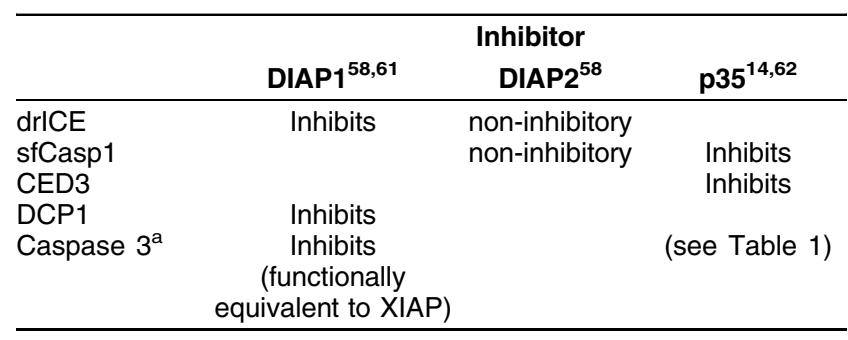

aMammalian caspase valuable drugs in reducing cell death in acute situations, such as heart attacks and stroke, and possibly in chronic diseases characterized by cell death, such as neurodegenerative disease. These caspase inhibitors might also be useful in reducing cell death in organs awaiting transplant, or to reduce apoptosis of normal cells caused by chemotherapeutic drugs used to treat cancer.

The first reports of in vitro use of caspase inhibitory drugs were in models of hepatitic in which lever damage was induced by anti-CD95 antibodies. Intravenous injections of Z-VAD-FMK prevented signs of liver damage and allowed all mice to recover from a treatment that was otherwise fatal within $3 \mathrm{~h} .{ }^{50}$ Another group found that mice pretreated with z-VAD-FMK were protected from liver injury caused by ligation of CD95 or from TNF $\alpha$ induced liver injury. ${ }^{51}$ YVAD-CMK was also reported to inhibit hepatic apoptosis induced by an anti-CD95 antibody or TNF administration. ${ }^{52}$

In a myocardial ischemia model intravenously administered $\mathrm{zVAD}-F M K$ reduced damage to heart muscle in rats subjected to a 30-min coronary occlusion followed by reperfusion. Treatment correlated with a decrease in cardiomyocyte apoptosis. ${ }^{53}$ In another study of a middle cerebral artery occlusion/reperfusion model, neuronal damage decreased after intraventricular injections of $z-$ VAD-FMK, YVAD-CMK, or DEVD-FMK. There was reduced tissue damage, brain swelling, and behavioral deficits. ${ }^{54}$ When given intrathecally $3 \mathrm{~h}$ following cerebral hypoxiaischemia, Boc-Asp-FMK provided significant neuroprotection. ${ }^{55}$

In a model of bacterial meningitis, z-VAD-FMK inhibited neuronal cell death in the hippocampus and reduced the inflammatory infiltrate into the cerebral spinal fluid. In this model it was demonstrated that the host response to pneumococcal infection was the principal contributor to the pathophysiology. ${ }^{56}$

In interpreting all the above results it should be remembered that the caspase inhibitors used were generally the halomethyl ketone inhibitors which have a broad spectrum of activity and may potently inhibit multiple caspases, including those involved in inflammatory reactions and other biological processes as well as apoptosis. For instance, the use of z-VAD-FMK in bacterial meningitis produced a protective effect similar to dampening the host immune response alone. In this instance, the caspase inhibitor seems to be acting, in part at least, as an antiinflammatory drug. ${ }^{56}$ Further, the potent effect of YVADCMK in inhibiting CD95 mediated hepatic injury is presumably via its effect on Caspase 1 which is not required for CD95-mediated apoptosis. ${ }^{52}$

While such clinical effects seem promising and legitimize caspases as potential therapeutic targets, major issues of drug delivery, specificity and permeability among others loom as significant hurdles, and these difficulties will be even greater if the caspase inhibitors are to be used for chronic degenerative diseases. Nevertheless progress in the field has been extraordinarily rapid to date, and with the enormous resources of most of the major pharmaceutical companies being brought to bear, further rapid advances should be expected. 


\section{References}

1. Ray CA, Black RA, Kronheim SR, Greenstreet TA, Sleath PR, Salvesen GS and Pickup DJ (1992) Viral inhibition of inflammation: cowpox virus encodes an inhibitor of the interleukin-1 beta converting enzyme. Cell 69: 597-604

2. McFadden G, Graham K, Ellison K, Barry M, Macen J, Schreiber M, Mossman K, Nash P, Lalani A and Everett H (1995) Interruption of cytokine networks by poxviruses: lessons from myxoma virus. J. Leukocyte Biol. 57: 731-738

3. Ray CA and Pickup DJ (1996) The mode of death of pig kidney cells infected with cowpox virus is governed by the expression of the crmA gene. Virology 217: $384-391$

4. Los M, Vandecraen M, Penning LC, Schenk H, Westendorp M, Baeuerle PA, Droge W, Krammer PH, Fiers W and Schulzeosthoff K (1995) Requirement of an ICE/Ced-3 protease for Fas/APO-1-mediated apoptosis. Nature 375: 81-83

5. Tewari M and Dixit VM (1995) Fas- and tumor necrosis factor-induced apoptosis is inhibited by the poxvirus crmA gene product. J. Biol. Chem. 270: 3255-3260

6. Varfolomeev EE, Schuchmann M, Luria V, Chiannilkulchai N, Beckmann JS, Mett IL, Rebrikov D, Brodianski VM, Kemper OC, Kollet O, Lapidot T, Soffer D, Sobe T, Avraham KB, Goncharov T, Holtmann H, Lonai P and Wallach D (1998) Targeted disruption of the mouse Caspase 8 gene ablates cell death induction by the TNF receptors, Fas/APO1, and DR3 and is lethal prenatally. Immunity 9: 267-276

7. Zhou Q, Snipas S, Orth K, Muzio M, Dixit VM and Salvesen GS (1997) Target protease specificity of the viral serpin crmA-analysis of five caspases. J. Biol. Chem. 272: 7797-7800

8. Garcia-Calvo M, Peterson EP, Leiting B, Ruel R, Nicholson DW and Thornberry NA (1998) Inhibition of human caspases by peptide-based and macromolecular inhibitors. J. Biol. Chem. 273: 32608-32613

9. Srinivasula SM, Ahmad M, Fernandesalnemri T, Litwack G and Alnemri ES (1996) Molecular ordering of the Fas-apoptotic pathway-the Fas/APO-1 protease Mch5 is a crmA-inhibitable protease that activates multiple ced-3/ICElike cysteine proteases. Proc. Natl. Acad. Sci. USA 93: 14486-14491

10. Kuida K, Haydar TF, Kuan CY, Gu Y, Taya C, Karasuyama H, Su M, Rakic P and Flavell RA (1998) Reduced apoptosis and cytochrome c-mediated caspase activation in mice lacking Caspase 9. Cell 94: 325-337

11. Smith KGC, Strasser A and VauxDL (1996) CrmA expression in Tlymphocytes of transgenic mice inhibits CD95 (Fas/APO-1)-transduced apoptosis, but does not cause lymphadenopathy or autoimmune disease. EMBO J. 15: 5167-5176

12. Komiyama T, Ray CA, Pickup DJ, Howard AD, Thornberry NA, Peterson EP and Salvesen $G$ (1994) Inhibition of Interleukin-1-Beta converting enzyme by the cowpox virus serpin $\mathrm{CrmA}$ - an example of cross-class inhibition. J. Biol. Chem. 269: $19331-19337$

13. Whisstock J, Lesk AM and Carrell R (1996) Modeling of serpin-protease complexes - antithrombin-thrombin, alpha(1)-antitrypsin (358met-arg)-thrombin, alpha(1)-antitrypsin (358met-arg)-trypsin, and antitrypsin-elastase. Proteins 26: $288-303$

14. Xue D and Horvitz HR (1995) Inhibition of the Caenorhabditis elegans cell-death protease ced-3 by a ced-3 cleavage site in baculovirus p35 protein. Nature 377: 248-251

15. Ekert PG, Silke J and Vaux DL (1999) Inhibition of apoptosis and clonogenic survival of cells expressing crmA variants: optimal caspase substrates are not necessarily optimal inhibitors. EMBO J. 18: 330-338

16. Wright ME, Han DK, Carter L, Fields S, Schwartz SM and Hockenbery DM (1999) Caspase-3 inhibits growth in Saccharomyces cerevisiae without causing cell death. FEBS Lett. 446: 9-14

17. Bird CH, Sutton VR, Sun JR, Hirst CE, Novak A, Kumar S, Trapani JA and Bird PI (1998) Selective regulation of apoptosis-the cytotoxic lymphocyte serpin proteinase inhibitor 9 protects against granzyme B-mediated apoptosis without perturbing the Fas cell death pathway. Mol Cell. Biol. 18: 6387-6398

18. Bird PI (1999) Regulation of pro-apoptotic leukocyte granule serine proteinases by intracellular serpins. Immunol. Cell Biol. 77: 47-57

19. Clem RJ, Fechheimer M and Miller LK (1991) Prevention of apoptosis by a baculovirus gene during infection of insect cells. Science 254: 1388-1390

20. Zhou Q, Krebs JF, Snipas SJ, Price A, Alnemri ES, Tomaselli KJ and Salvesen GS (1998) Interaction of the baculovirus anti-apoptotic protein p35 with caspases-specificity, kinetics, and characterization of the caspase/p35 complex. Biochemistry 37: 10757-10765

21. Hay BA, Wolff T and Rubin GM (1994) Expression of baculovirus p35 prevents cell death in Drosophila. Development 120:2121-2129
22. White K, Tahaoglu E and Steller H (1996) Cell killing by the Drosophila gene reaper. Science 271: 805-807

23. Izquierdo M, Grandien A, Criado LM, Robles S, Leonardo E, Albar JP, de Buitrago GG and Martinez AC (1999) Blocked negative selection of developing T cells in mice expressing the baculovirus p35 caspase inhibitor. EMBO J. 18: $156-166$

24. Crook NE, Clem RJ and Miller LK (1993) An apoptosis inhibiting baculovirus gene with a zinc finger like motif. J. Virol. 67: 2168-2174

25. Uren AG, Coulson EJ and Vaux DL (1998) Conservation of baculovirus inhibito of apoptosis repeat proteins (BIRps) in viruses, nematodes, vertebrates and yeasts. Trends Biochem. Sci. 23: 159-162

26. LaCasse EC, Baird S, Korneluk RG and MacKenzie AE (1998) The inhibitors of apoptosis (IAPs) and their emerging role in cancer. Oncogene 17: $3247-3259$

27. Fraser AG, James C, Evan Gl and Hengartner MO (1999) Caenorhabditis elegans inhibitor of apoptosis protein (IAP) homologue BIR-1 plays a conserved role in cytokinesis. Curr. Biol. 9: 292-301

28. Li FZ, Ambrosini G, Chu EY, Plescia J, Tognin S, Marchisio PC and Altieri DC (1998) Control of apoptosis and mitotic spindle checkpoint by survivin. Nature 396: $580-584$

29. Uren AG, Beilharz T, O'Connell MJ, Bugg SJ, van Driel R, Vaux DL and Lithgow T (1999) Role for yeast inhibitor of apoptosis (IAP)-like proteins in cell division. Proc. Natl. Acad. Sci. USA 96: 10170-10175

30. Hay BA, Wassarman DA and Rubin GM (1995) Drosophila homologs of baculovirus inhibitor of apoptosis proteins function to block cell death. Cell 83 $1253-1262$

31. Vucic D, Kaiser WJ and Miller LK (1998) Inhibitor of apoptosis proteins physically interact with and block apoptosis induced by Drosophila proteins hid and grim. Mol. Cell. Biol. 18: $3300-3309$

32. Vucic D, KaiserWJ and Miller LK. (1998) A mutational analysis of the baculovirus inhibitor of apoptosis Op-IAP. J. Biol. Chem. 273: 33915-33921

33. Miller LK (1997) Baculovirus interaction with host apoptotic pathways. J. Cell. Physiol. 173: 178-182

34. Vucic D, Kaiser WJ, Harvey AJ and Miller LK (1997) Inhibition of reaper-induced apoptosis by interaction with inhibitor of apoptosis proteins (IAPs). Proc. Natl. Acad. Sci. USA 94: 10183-10188

35. Mccall K and Steller H (1997) Facing death in the fly-genetic analysis of apoptosis in Drosophila. Trends Genet. 13: 222-226

36. Wang SL, Hawkins CJ, Yoo SJ, Müller H-AJ and Hay BA (1999) The Drosophila caspase inhibitor DIAP1 is essential for cell survival and is negatively regulated by HID. Cell 98: $453-463$

37. Deveraux QL, Takahashi R, Salvesen GS and Reed JC (1997) X-linked IAP is a direct inhibitor of cell-death proteases. Nature 388: 300-304

38. Tamm I, Wang Y, Sausville E, Scudiero DA, Vigna N, Oltersdorf T and Reed JC (1998) IAP-family protein Survivin inhibits caspase activity and apoptosis induced by Fas (CD95), Bax, caspases, and anticancer drugs. Cancer Res. 58 $5315-5320$

39. Takahashi R, Deveraux Q, Tamm I, Welsh K, Assamunt N, Salvesen GS and Reed JC (1998) A single BIR domain of XIAP is sufficient for inhibiting caspases. J. Biol. Chem. 273: 7787-7790

40. Roy N, Deveraux QL, Takahashi R, Salvesen GS and Reed JC (1997) The C-IAP1 and C-IAP-2 proteins are direct inhibitors of specific caspases. EMBO J. 16 $6914-6925$

41. Deveraux QL, Roy N, Stennicke HR, Vanarsdale T, Zhou Q, Srinivasula SM, Alnemri ES, Salvesen GS and Reed JC (1998) IAPs block apoptotic events induced by Caspase-8 and cytochrome c by direct inhibition of distinct caspases. EMBO J. 17: 2215-2223

42. Ambrosini G, Adida C and Altieri DC (1997)Anovel anti-apoptosis gene, survivin expressed in cancer and lymphoma. Nature Med. 3: 917-921

43. Jurgensmeier JM, Xie ZH, Deveraux Q, Ellerby L, Bredesen D and Reed JC (1998) Bax directly induces release of cytochrome c from isolated mitochondria. Proc. Natl. Acad. Sci. USA 95: 4997-5002

44. Sun JR, Bottomley SP, Kumar S and Bird PI (1997) Recombinant Caspase-3 expressed in Pichia Pastoris is fully activated and kinetically indistinguishable from the native enzyme. Bioch. Biophys. Res. Comm. 238: $920-924$

45. Thornberry NA, Peterson EP, Zhao JJ, Howard AD, Griffin PR and Chapman KT (1994) Inactivation of interleukin-1 beta converting enzyme by peptide (acyloxy)methyl ketones. Biochemistry 33: 3934-3940 
46. Thornberry NA, Miller DK and Nicholson DW (1995) Interleukin-1 $\beta$ converting enzyme and related proteases as potential targets in inflammation and apoptosis. Perspectives in Drug Discovery and Design 2: 389-399

47. Thornberry NA, Ranon TA, Pieterson EP, Rasper DM, Timkey T, Garciacalvo M Houtzager VM, Nordstrom PA, Roy S, Vaillancourt JP, Chapman KT and Nicholson DW (1997) A combinatorial approach defines specificities of members of the caspase family and granzyme B - functional, relationships established for key mediators of apoptosis. J. Biol. Chem. 272: 17907-17911

48. Schotte P, Declercq W, Van Huffel S, Vandenabeele P and Beyaert R (1999) Non-specific effects of methyl ketone peptide inhibitors of caspases. FEBS Lett. 442: $117-121$

49. Margolin N, Raybuck SA, Wilson KP, Chen WY, Fox T, Gu Y and Livingston DJ (1997) Substrate and inhibitor specificity of interleukin-1-beta-converting enzyme and related caspases. J. Biol. Chem. 272: 7223-7228

50. Rodriguez I, Matsuura K, Ody C, Nagata S and Vassalli P (1996) Systemic injection of a tripeptide inhibits the intracellular activation of CPP32-like proteases in vivo and fully protects mice against Fas-mediated fulminant liver destruction and death. J. Exp. Med. 184: 2067-2072

51. Kunstle G, Leist M, Uhlig S, Revesz L, Feifel R, Mackenzie A and Wendel A (1997) ICE-protease inhibitors block murine liver injury and apoptosis caused by CD95 or by TNF-alpha. Immunol. Lett. 55: 5-10

52. RouquetN, Pages JC, Molina T, Briand P and Joulin V (1996) Ice inhibitor YVAD$\mathrm{CMK}$ is a potent therapeutic agent against in vivo liver apoptosis. Curr. Biol. 6 1192-1195

53. Yaoita H, Ogawa K, Maehara Kand Maruyama Y (1998) Attenuation of ischemia/ reperfusion injury in rats by a caspase inhibitor. Circulation 97: 276-281

54. Hara H, Friedlander RM, Gagliardini V, Ayata C, Fink K, Huang Z, ShimizuSasamata M, Yuan J and Moskowitz MA (1997) Inhibition of interleukin 1beta converting enzyme family proteases reduces ischemic and excitotoxic neuronal damage. Proc. Natl. Acad. Sci. USA 94: 2007-2012
55. Cheng Y, Deshmukh M, Dcosta A, Demaro JA, Gidday JM, Shah A, Sun YL, Jacquin MF, Johnson EM and Holtzman DM (1998) Caspase inhibitor affords neuroprotection with delayed administration in a rat model of neonatal hypoxicischemic brain injury. J. Clin. Invest. 101: 1992-1999

56. Braun JS, Novak R, Herzog KH, Bodner SM, Cleveland JL and Tuomanen EI (1999) Neuroprotection by a caspase inhibitor in acute bacterial meningitis. Nat. Med. 5: 298-302

57. Bump NJ, Hackett M, Hugunin M, Seshagiri S, Brady K, Chen P, Ferenz C, Franklin S, Ghayur T, Li P, Mankovich J, Shi LF, Greenberg AH, Miller LK and Wong WW (1995) Inhibition of ICE family proteases by baculovirus antiapoptotic protein p35. Science 269: 1885-1888

58. Kaiser WJ, Vucic D and Miller LK (1998) The Drosophila inhibitor of apoptosis DIAP1 suppresses cell death induced by the caspase drICE. FEBS Lett. 440: $243-248$

59. Uren AG, Pakusch M, Hawkins CJ, Puls KL and Vaux DL (1996) Cloning and expression of apoptosis inhibitory protein homologs that function to inhibit apoptosis and/or bind tumor necrosis factor receptor-associated factors. Proc. Natl. Acad. Sci. USA. 93: 4974-4978

60. Hawkins CJ, Uren AG, Hacker G, Medcalf RL and Vaux DL (1996) Inhibition of interleukin 1-beta-converting enzyme-mediated apoptosis of mammalian cells by baculovirus IAP. Proc. Natl. Acad. Sci. USA 93: 13786-13790

61. Hawkins CJ, Wang,SL and Hay BA (1999) A cloning method to identify caspases and their regulators in yeast: identification of Drosophila IAP1 as an inhibitor of the Drosophila caspase DCP-1. Proc. Natl. Acad. Sci. USA 96: 2885-2890

62. Ahmad M, Srinivasula SM, Wang,LJ, Litwack G, Fernandesalnemri T and Alnemri ES (1997) Spodoptera frugiperda caspase-1, a novel insect death protease that cleaves the nuclear immunophilin FKBP46, is the target of the baculovirus antiapoptotic protein p35. J. Biol. Chem. 272: 1421-1424 